Vol. 4, No. 1, 2019

\title{
UTILISING ORGANIC-MINERAL FERTILISERS PRODUCED FROM MAN-MADE WASTE OF POULTRY FARMS
}

\author{
Ivan Tymchuk, Maria Kanda, Myroslav Malovanyy \\ Lviv Polytechnic National University, \\ Department of Ecology and Sustainable, Environmental Management, \\ 12, S. Bandery Str., Lviv, 79013, Ukraine \\ i.s.tymchuk@gmail.com
}

https://doi.org/10.23939/ep2019.01.057

Received: 10.03 .2019

(c) Tymchuk I., Kanda M., Malovanyy M., 2019

\begin{abstract}
This research is devoted to ecological problems associated with the development of poultry farming in Ukraine. It provides practical approach to the reduction of ammonium emissions from poultry farms, which results in an opportunity to produce organicmineral fertiliser. Organic-mineral fertilisers obtained this way were tested in field.
\end{abstract}

Key words: poultry farms, man-made waste, organicmineral fertilisers, field tests.

\section{Introduction}

Today, poultry farming is one of the most prioritised areas of animal industry. Rapid development of poultry farming in Ukraine is accompanied by the increase of production of eggs, meats and poultry stock. First of all, this is explained by the growth of demand of food companies and people for poultry products due to its relative cheapness as compared to other types of meat [1]. It turned out that poultry industry was capable of prompt adaptation to the marketing conditions by virtue of its mobility under transformation of the agroindustrial complex.

As to localisation of poultry farms on the territory of Ukraine, there are few industry leaders holding up to $70 \%$ of poultry stock in the country. 6-13\% of overall poultry sock are localised in Kyiv, Cherkasy, Vinnytsia, Kherson and Dnipropetrovsk Regions [2]. Poultry production is concentrated in the Forest-Steppe Zone. Fast return on investment in poultry production makes investment increase dynamics tending to rapid growth. This contributes to quick rise of the number of big modern poultry farms, and creation and development of powerful verticalintegrated companies. In 2017 poultry production in the Forest-Steppe Zone reached 857.68 ths $t$ of meat, making $71 \%$ of overall production output in Ukraine. The poultry production output was $20.5 \%$ in the Steppe Zone and
$8.5 \%$ in Polissia. The leaders of poultry production are Cherkasy Region - $23 \%$, Vinnytisa Region - 18.9\%, Dnipropetrovsk Region - $14 \%$, Kyiv Region - $13.6 \%$, and Volyn Region, which share in overall poultry production is $5.8 \%$.

Expert assessments indicate that farming generates up to $20 \%$ of all pollution emissions in all components of the environment: atmosphere, hydrosphere and lithosphere. And poultry farming is referred to the biggest environmental polluters of all agricultural productions [3].

The authors [4] place an emphasis on sources of ecological hazard of poultry farms of Ukraine pertinent to the generation of solid wastes, which cause further transition of pollution into the atmosphere and hydrosphere. These sources together with the approximate waste output (with the consideration of only specialised farms) are provided below:

1. Droppings with natural moisture content $5.2 \mathrm{mln} \mathrm{t}$;

2. Died birds -50 ths $\mathrm{t}$

3. Bird slaughter waste -210 ths $t$

4. Incubation waste -12 ths $t$

The second, third and fourths types of wastes require special measures and processes for their disposal, implementation of which is mandatory for all poultry farms, and operation of farms without them is unacceptable. Therefore, we did not take them into account in the sources of ecological hazard in the operation of poultry farms. Nevertheless, according to those authors [5], the most massive wastes are droppings - metabolic byproduct of birds. Also, we did not consider micro- and macrobiological contamination of the environment (microorganisms, helminths, flies, etc.), which are secondary pollutants, and their intensity of impact would be significantly reduced together with successful resolution of the task of minimizing ecological hazard caused by poultry 
droppings. These researches consider chicken droppings as the main cause of ecological hazard in the area of impact of poultry farms.

Based on the assumptions above, the sources of ecological hazard are closely related to places of localisation and routes of transportation of poultry droppings. Waste accumulation significantly depends on a used farming process and equipment utilised to maintain this process [6]. These indicators also have influence on the moisture content of wastes, which can vary from $82-98 \%$ (when using scraping system for droppings removal from battery cages) to 55-65\% (when using belt conveyors) and to 20-50\% (when using ventilated belt conveyors, [7]).

Thus, we can outline 3 potential sources of ecological hazard in the area of impact and localisation of birds (poultry farms, complexes, private households):

- site for keeping birds (generation of droppings) - the main impact is caused on the atmosphere;

- $\quad$ system of droppings transportation - the main impact is caused on the atmosphere;

- $\quad$ sites (locations) for droppings storage - the main impact is caused on the atmosphere, hydrosphere and lithosphere.

According to the authors [8], average loss of separate components of droppings in process of their generation, transportation and storage makes around $10 \%$, and as to elements like nitrogen, it is up to 20 $50 \%$. The main part of nitrogen converts into ammonium form and contaminates the atmosphere and hydrosphere.

The first source, which is a site for keeping birds, is the major one, because the stage of birds housing is associated with the generation of ecological hazard posed by poultry droppings, which further extends to the process of transportation and storage of droppings. In order to assess the amount of ammonia released by the first source, it is necessary to take into account a number of birds kept per year, a method of keeping (i.e. litter or litter-free method for broilers; battery cages, floor housing, colony cages, multilevel floor, free-range keeping for egg-laying chicken, etc.), sequence of keeping cycles aimed at preventive maintenance of premises, type of birds (meet poultry, laying chicken), season conditions and microclimate of birds housing, etc. Certainly, it is difficult to estimate these factors throughout the country, especially in the absence of statistical information specially collected by specific indicators. We think that in order to assess the level of ecological hazard in the area of impact of sites for keeping birds, it is reasonable to use averaged indicators, which allow to evaluate the effect of actions proposed in the research, targeted at minimisation of this ecological hazard.
Based on simulated conditions, we calculated the overall emission of ammonia in respect of the first source throughout the territory of Ukraine, which is $761.5 \mathrm{~kg}$ per hour, $28.27 \mathrm{t}$ per 24 hours, and $6670 \mathrm{t}$ per year.

It is next to impossible to analyse the pollution volume generated by the second and thirds sources, because it requires considering individual conditions of droppings transportation, storage as well as adopted strategy of their disposal at each farm.

The prospective way to minimise ecological hazard at sites for keeping birds is to apply sorbents in litter composition, which adsorb part of ammonia released by chicken droppings $[9,10]$. This will ensure the reduction of ammonia emissions polluting the atmosphere as a result of it intake by adsorbents. At the same time, these adsorbents containing ammonia can be used as efficient long-acting nitrogenous fertiliser. In process of our conducted studies (Table 1), we estimated that the optimal composition of litter is at the ratio of palygorskite + clinoptilolite (1:1) to poultry manure $-1: 5$.

Table 1

\section{Estimation of optimal ratio of mixture of natural dispersive sorbents to litter}

\begin{tabular}{|c|c|}
\hline $\begin{array}{c}\text { Ratio of palygorskite }+ \\
\text { clinoptilolite }(1: 1) \text { mixture } \\
\text { to litter }\end{array}$ & $\begin{array}{c}\text { Weight of absorbed } \\
\text { ammonia, mg-eq/g } \\
\text { of sorbents } \cdot\end{array}$ \\
\hline $1: 6$ & 0.92 \\
\hline $1: 5.5$ & 1.3 \\
\hline $1: 5$ & 1.56 \\
\hline $1: 4$ & 1.5 \\
\hline $1: 3.5$ & 1.1 \\
\hline $1: 3$ & 0.84 \\
\hline $1: 2.5$ & 0.34 \\
\hline
\end{tabular}

The highest capacity for ammonia adsorption was shown by the composition "sorbents : chicken droppings" at the ratio of 1:5. It makes about $1.56 \mathrm{mg}-$ eq/g of sorbents. This method of production of granulated organic-mineral fertiliser using litter as raw material with the sorbents composition above was granted a utility model patent [11].

Certainly, application of sorbents is hardly expected to completely eliminate pollution of the atmosphere with ammonia in the area of impact of poultry farms. In order to entrap ammonium residuals, ventilation systems should be equipped with ammonia entrapment by regular absorption method (absorption by acidic solutions seems the most efficient to us). However, it is necessary to consider that the amount of released ammonia at the stage of birds keeping drops more than 6 times by binding into valuable fertilisers of durable action.

Organic-mineral fertilisers produced from wastes successfully passed laboratory tests. 
Field tests were proposed to be conducted using crop plants, as they require nitrogen most of all.

In order to raise the yield of forage lands in the Lviv Region, amelioration is required on the area of 35-40 ths ha, including around 20 ths ha of fertile hayfields. High yields of herbage and hay are provided by ryegrass planting by single-crop and mixed sowing. It is important for young plants to grow intensively in the year of sowing. Development of grasses during the first year greatly depends on overwintering of plants and hay and seed yield in the next year.

Underdeveloped grasses reach normal growth only in the second year of life. These grasses winter badly, suffer from diseases more and provide low seed yield.

Along with the acceleration of scientific and technical progress, intensive technologies used in production must be energy saving. It is estimated that resource-saving technologies contribute to the decrease in utilisation of mineral fertilisers by $25-30 \%$, fuel by 5-7\%, and pesticides by 4-6\%. Production of $1 \mathrm{~kg}$ of seeds of perennial grasses takes 700-800 kcal of nonrenewable energy, while conventional technology takes $1000-2000 \mathrm{kcal}$.

Implementation of energy-efficient and saving technologies will facilitate the improvement of ecological situation in the environment and the increase of soil fertility, while cutting costs for production.

Therefore, it is important to be aware of the effect of different types of organic-mineral fertilisers on the yield and quality of annual ryegrass seeds.

\section{Methods and Materials}

Efficiency of organic-mineral fertilisers in field was studied by common technique [12] during 2017-2018 in sod-podzolic medium-acidic soil on bare surface at the site of the Agricultural Institute of the Carpathian Region of the National Academy of Agricultural Sciences of Ukraine with the study of the effect of different organic-mineral fertilisers on growth and development of annual ryegrass of Zhaivir variety. Within the vegetation period the following was defined: plant height before gathering, number of plants per $1 \mathrm{~m}^{2}$, and harvest structure (length of inflorescence, amount of seeds from one plant, and weight of seeds). Seed yield accounting was performed with the determination of qualitative indicators of seeds.

The study pattern included the following variants:

- Control (no fertilisation);

- 1 (poultry manure + palygorskite, $5: 1$ )

- 2 (poultry manure + clinoptilolite, 5:1)

- 3 (poultry manure, no additives)

- 4 (poultry manure + palygorskite + clinoptilolite, 10:1:1)

Meteorological conditions of the vegetation period of 2017-2018 are shown in Fig 1, 2. In general, the vegetation period is characterised by higher temperature as compared to long-term annual indicators, as well as significant variation of the amount of precipitations.

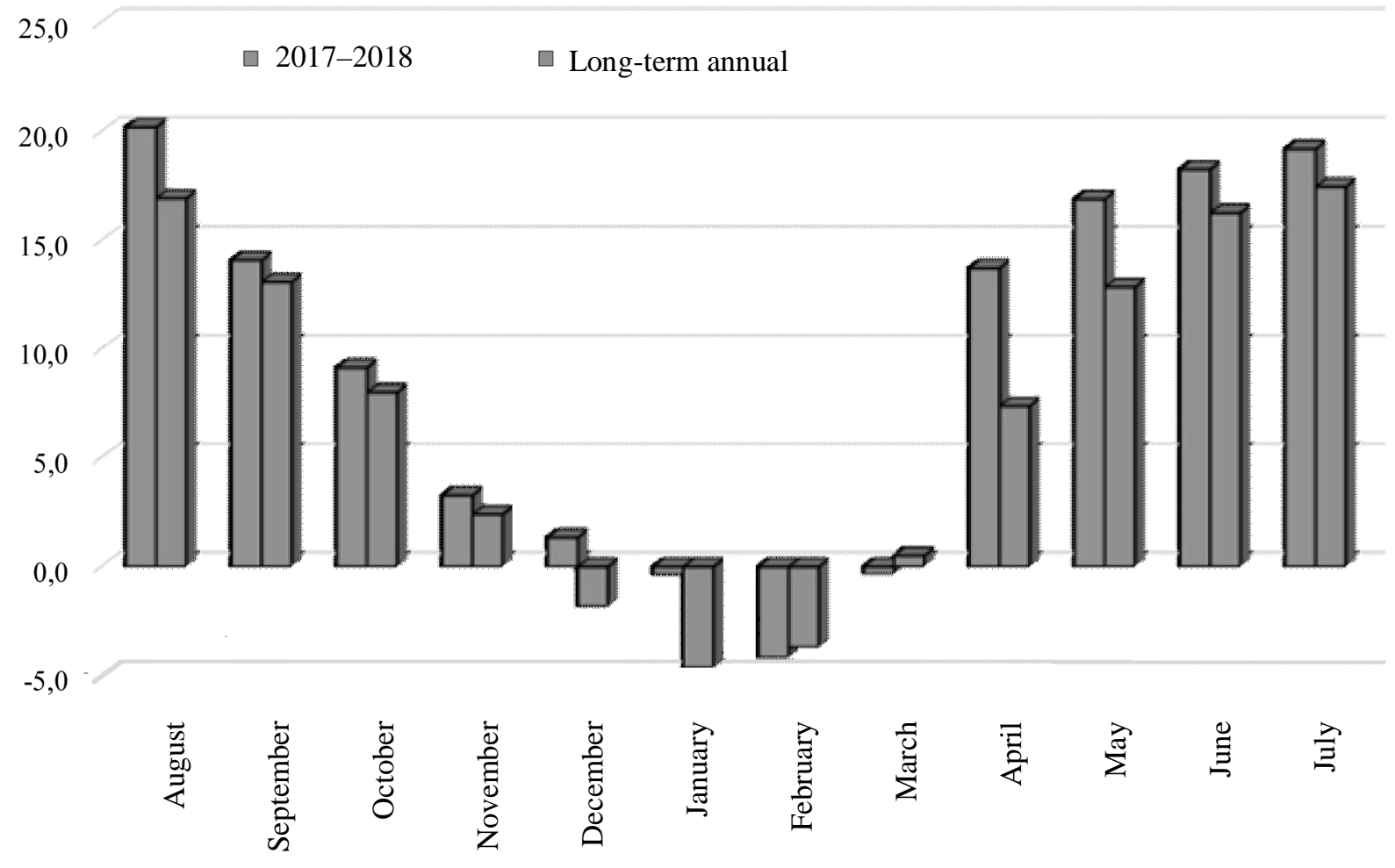




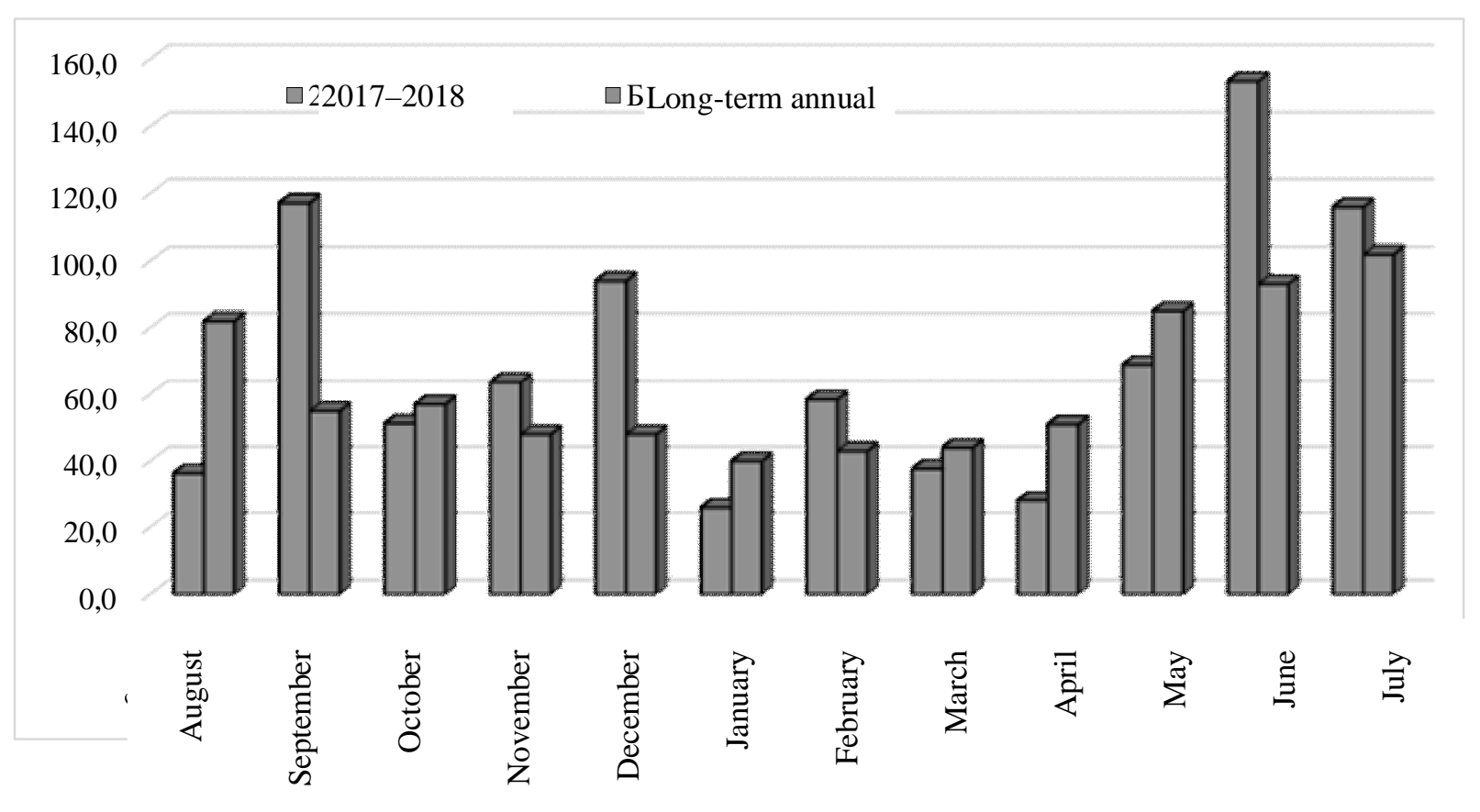

Fig. 2. Precipitations during vegetation period, $\mathrm{mm}$

\section{Results and Discussion}

Annual ryegrass of Zhaivir variety is a winter tetraploid plant characterised by high tolerance for winter and frost conditions, and well adapted to cultivation in soil and climate zones of Forest-Steppe and Polissia. This variety provides $3-4$, and with irrigation 4-6 cuts of herbage, which significantly surpasses other crops by digestibility and palatability. The potential yield of Zhaivir variety is 800$1000 \mathrm{dt} /$ ha of herbage, dry matter is $100-150 \mathrm{dt} / \mathrm{ha}$, feed unit is $90-105 \mathrm{dt} / \mathrm{ha}$, digestive protein is $20-25 \mathrm{dt} / \mathrm{ha}$, and seed is $10-11 \mathrm{dt} / \mathrm{ha}$. Zhaivir variety can be preserved in the grass stand up to 3 years, which contributes to the increased yield of hayfields and pastures in the first years of use.

Study tests of the effect of the fertilisation variants of annual ryegrass on seeds started on 11 August 2017 ( 5 variants in 4 cycles, the study pattern is provided above).
Plants of annual ryegrass of Zhaivir variety as well as other crop grasses were growing differently in the first year, depending much on weather conditions.

Weather conditions of the vegetation period of 2017-2018 were unstable (Pictures 1 and 2), with insufficient precipitations during most of the months and increased temperatures. Nevertheless, in general the amount of precipitations from August 2017 to July 2018 exceeded the long-term average annual norm by $103 \mathrm{~mm}$, and average annual temperature was higher of the norm by $2.2^{\circ} \mathrm{C}$. These weather conditions favoured the growth of perennial grasses.

Observations indicate that the duration of the period from sowing to initial germination depends on meteorological conditions and fertilisation system rather than sowing terms (Table 2).

Specifics of growth and development of annual ryegrass of Zhaivir variety in the first year depending on fertilisation (average for 2017)

\begin{tabular}{|c|c|c|c|c|c|}
\hline \multirow[b]{2}{*}{ Variants } & \multicolumn{2}{|c|}{ Days after sowing to: } & \multicolumn{2}{|c|}{ Days after complete germination to: } & \multirow{2}{*}{$\begin{array}{l}\text { Density of grass stand, } \\
\text { pcs } / \mathrm{m}^{2}\end{array}$} \\
\hline & initial germination & $\begin{array}{l}\text { complete } \\
\text { germination }\end{array}$ & initial tillering & $\begin{array}{l}\text { complete } \\
\text { tillering }\end{array}$ & \\
\hline \multicolumn{6}{|c|}{ Summer coverless row sowing } \\
\hline $\begin{array}{c}\text { Control } \\
\text { (no fertilisation) }\end{array}$ & 16 & 20 & 24 & 36 & 754 \\
\hline 1 & 16 & 20 & 24 & 36 & 747 \\
\hline 2 & 16 & 20 & 24 & 36 & 748 \\
\hline 3 & 16 & 20 & 24 & 36 & 765 \\
\hline 4 & 16 & 20 & 24 & 36 & 758 \\
\hline
\end{tabular}


Summer sowing of annual ryegrass was conducted on 11 August 2017. The period from complete germination to complete tillering lasted 36 days. The plants started winter in a phase of complete tillering and good condition.

In 2018 plants of annual ryegrass of Zhaivir variety renewed second-year vegetation on 8-30 March. Stem elongation of plants ended after 46-47 days.

The highest density of the grass stand, $960 \mathrm{pcs} / \mathrm{m}^{2}$, was observed in solid row planting with fertilisation variant No. 4. Average height of the plants was $93-100 \mathrm{~cm}$. Fertilisation of planting of annual ryegrass resulted in the extension of the periods of the phenological phase of development from the beginning of aftergrowth to the phase of stem elongation for 2-4 days and earing for 15 days as compared to the control.

Analysis of the harvest structure showed that the seed yield of annual ryegrass of Zhaivir variety under the effect of fertilisation variants varied as a result of increase or decrease of the number of generative shoots per $1 \mathrm{~m}^{2}$ (Table 3).

Our study variants of fertilisation influenced both the annual ryegrass yield and seed quality. Mathematical processing of the received data demonstrated a significant effect of the application of organic-mineral fertilisers on the seed yield of annual ryegrass of Zhaivir variety (Table 4).

Table 3

\section{Beginning of aftergrowth and average duration of inter-phase periods depending on seeding norms and sowing term}

\begin{tabular}{|c|c|c|c|c|c|}
\hline \multirow{2}{*}{ Variants } & \multirow{2}{*}{$\begin{array}{l}\text { Outermost dates } \\
\text { of the beginning } \\
\text { of aftergrowth }\end{array}$} & \multicolumn{2}{|c|}{ Days after the beginning of aftergrowth to: } & \multirow{2}{*}{$\begin{array}{c}\text { Density of grass } \\
\text { stand, } \\
\mathrm{pcs} / \mathrm{m}^{2} \\
\end{array}$} & \multirow[t]{2}{*}{$\begin{array}{c}\text { Plant height, } \\
\mathrm{cm}\end{array}$} \\
\hline & & stem elongation & earing & & \\
\hline \multicolumn{6}{|c|}{ Summer solid row planting } \\
\hline $\begin{array}{c}\text { Control } \\
\text { (no fertilisation) }\end{array}$ & 28.03 & 54 & 64 & 905 & 93 \\
\hline 1 & 30.03 & 55 & 65 & 914 & 98 \\
\hline 2 & 29.03 & 57 & 69 & 943 & 100 \\
\hline 3 & 29.03 & 56 & 66 & 935 & 99 \\
\hline 4 & 31.03 & 58 & 69 & 960 & 100 \\
\hline
\end{tabular}

Effect of fertilisation on seed yield and quality

Table 4

\begin{tabular}{|c|c|c|c|c|c|}
\hline \multirow{2}{*}{ Variants } & \multirow{2}{*}{$\begin{array}{l}\text { Germination } \\
\text { capacity, \% }\end{array}$} & \multirow{2}{*}{$\begin{array}{l}\text { Weight of } 1000 \\
\text { seeds, g }\end{array}$} & \multirow{2}{*}{$\begin{array}{l}\text { Yield, } \\
\text { t/ha }\end{array}$} & \multicolumn{2}{|c|}{ Difference vs. control, + } \\
\hline & & & & $\mathrm{t} / \mathrm{ha}$ & $\%$ \\
\hline \multicolumn{6}{|c|}{ Summer solid row planting } \\
\hline Control & 91 & 5.15 & 0.60 & - & - \\
\hline 1 & 93 & 5.16 & 0.77 & 0.17 & +28.3 \\
\hline 2 & 93 & 5.21 & 0.72 & 0.12 & +20.0 \\
\hline 3 & 93 & 5.18 & 0.69 & 0.09 & +15.0 \\
\hline 4 & 94 & 5.20 & 0.82 & 0.22 & +36.7 \\
\hline
\end{tabular}

In particular, application of organic-mineral fertilisers had a positive effect on the seed yield from a unit area - the difference with the control without fertilisation by the variants made from $0.09 \mathrm{t} / \mathrm{ha}(15.0 \%)$ to $0.22 \mathrm{t} / \mathrm{ha}(36.7 \%)$ with the lowest significant difference of $0.022 \mathrm{t} / \mathrm{ha}$. It was noticed that germination capacity of the received seeds tended to rise by $2-4 \%$ as compared to the control, and the weight of 1000 seeds increased from $5.15 \mathrm{~g}$ of the control without fertilisation to $5.21 \mathrm{~g}$ with fertilization variant No. 2 .

\section{Conclusion}

Based on the results of the conducted studies, we can draw a conclusion that production of this fertiliser will help to reduce the emission of ammonia into the environment. Application of organic-mineral fertiliser on a basis of poultry manure with mixture of natural sorbents to crop plants, in particular, annual ryegrass of Zhaivir variety, had a positive effect on growth and development of the plants and resulted in the increased yield by $\approx 20-37 \%$ in respect of the 
control, as well as by $\approx 5-22 \%$ in respect of regular poultry manure. Also, we noticed that germination capacity of the received seeds tended to rise by 2-4\% as compared to the control, and the weight of 1000 seeds increased from $5.15 \mathrm{~g}$ of the control without fertilisation to $5.21 \mathrm{~g}$ with fertilization variant No. 2.

\section{References}

[1] Terty`chna O. V., Borodaj V. P. Ekologichni zasady rozvytku promyslovogo ptaxivnycztva. Agroekologichnyi zhurnal. 2015. \#2. S. 6-12.

[2] Bezhenar I. M., Vasyuta T. M. Stan ta perspektyvy rozvytku ptaxivny`cztva v Ukrayini. Agrosvit. 2015. \#18. S. 41-51.

[3] Mel`ny`k V. O. Ekologichni problemy suchasnogo ptaxivnycztva: Mizhvidomchyj naukovyj tematychnyj zbirnyk „Ptaxivnycztvo”, 2009, vy`pusk 63. S. 1-15. Rezhym dostupu www.avian.org.ua.

[4] Tereshhenko O. V., Kateryny`ch O. O., Rozhkovs`ky`j O. V.: Suchasni napryamy rozvytku ptaxivnycztva Ukrayiny: stan ta perspektyvy naukovogo zabezpechennya galuzi. Efektyvne ptaxivnycztvo. 2011.\#11. S. 7-12.

[5] A. E. Ghaly and K. N. MacDonald. Development and testing of an ammonia removal unit from the exhaust gas of a manure drying system. American Journal of Environmental Science. 2013. Vol. 9, No. 1. P. 51-61.
[6] Pinchuk V. O., Terty`chna O. V., Borodaj V. P. Rozraxunok azotnogo balansu ptaxopidpry`yemstv. Agroekologichny`j zhurnal. 2016. \#4. S. 35-39.

[7] Savostyanova K. V., Melny`k V. O. Pidsushuvannya poslidu na strichkovyx transporterax klitkovyx batarej dlya utrymannya kurej-nesuchok : Mizhvidomchyj naukovyj tematy`chnyj zbirnyk "Ptaxivnycztvo". Kharkiv : IP UAAN. 2007, vypusk 59. S. 138-145.

[8] Heat stress in poultry production: Mitigation strategies to overcome the future challenges facing the global poultry industry / Nawab A. et al. Journal of Thermal Biology. 2018. Vol. 78, P. 131-139.

[9] İsmail Tosun. Ammonium removal from aqueous solutions by clinoptilolite: determination of isotherm and thermodynamic parameters and comparison of kinetics by the double exponential model and conventional kinetic models. International Journal of Environmental Research and Public Health. 2012. No. 9. P. 970-984.

[10] Schntider A. F. et al. Natural zeolites in diet or litter of broilers. British Poultry Science. 2016. Vol. 57, No. 2. P. 257-263.

[11] Patent na korysnu model 118020 Ukrayina, MPK S02F 3/02, S02G 3/04. 144. Sposib otrymannya organichnogo granulovanogo dobryva / Kanda M. I., Odnorig Z. S., Malovanyy M. S. (UA); zayavnyk ta patentovlasnyk Nacionalnyj Universytet „Lvivska Politexnika”. \# a 2016 12981; zayav. 19.12.2016; opubl. 25.07.2017.

[12] Dospexov B. A. Metodyka polevogo opyta [5-e izd., dop. i pererab.] / B. A. Dospexov. - M.: Agropromy`zdat, 1985. $-351 \mathrm{~s}$. 